\title{
Investigation of Some Microbiological and Chemical Properties of Different Cheeses
}

\author{
Sezen HARMANKAYA ${ }^{1 *}$, Ahmet HARMANKAYA ${ }^{2}$ \\ ${ }^{1}$ Kafkas University, Kars High Vocational School, Department of Food Processing, 36100 Kars, Turkey \\ ${ }^{2}$ Kafkas University, Faculty of Arts and Sciences, Department of Chemistry, 36100 Kars, Turkey \\ (ORCID: 0000-0003-2498-5003) (ORCID: 0000-0001-9923-6723)
}

\begin{abstract}
In this study, some microbiological and chemical analyses were performed on samples of kashar, chechil, lor and white cheeses produced in the region of Kars. The samples were microbiologically evaluated in means of total aerob mesophilic bacteria, coliform group bacteria, Escherichia coli, Enterobacteriaceae, StaphylococciMicrococci, yeast-mold, Salmonella spp. and Listeria monocytogenes. The $\mathrm{pH}$ values of cheese samples were determined by $\mathrm{pH}$-meter, acidity and salt content by titration method, fat content by Gerber method and moisture content by gravimetric method. The chemical analyses were completed and investigated for compliance with Turkish standards. Of the examined kashar cheese samples, 28\% in terms of salt content and $40 \%$ in terms of moisture content did not meet Turkish standards. Of the chechil cheese samples, $60 \%$ in terms of salt content and $40 \%$ in terms of moisture content did not meet Turkish standards. Of the lor cheese samples, $4 \%$ contained $L$. monocytogenes, while $20 \%$ in terms of salt content and $28 \%$ in terms of moisture content did not meet Turkish standards. Of the white cheese samples, $8 \%$ contained L. monocytogenes, while $48 \%$ in terms of salt content and $28 \%$ in terms of moisture content did not meet Turkish standards It was determined that some of the cheese samples examined in accordance with the obtained results may pose a risk in microbiological terms and do not comply with the relevant standards in terms of chemistry.
\end{abstract}

Keywords: Kashar, chechil, lor, white cheese, microbiological, chemical.

\section{Farklı Peynir Çeşitlerinin Bazı Mikrobiyolojik ve Kimyasal Özelliklerinin Araştırılması}

\section{$\ddot{O} \mathbf{z}$}

$\mathrm{Bu}$ araştırmada Kars yöresinde üretimi yapılan kaşar, çeçil, lor ve beyaz peynir örneklerinin mikrobiyolojik ve kimyasal özellikleri incelendi. Örnekler mikrobiyolojik olarak toplam aerob mezofilik bakteri, koliform grubu bakteri, E. coli, Enterobacteriaceae, Stafilokok-Mikrokok, maya-küf, Salmonella spp. ve L. monocytogenes yönünden değerlendirildi. Peynir örneklerinin $\mathrm{pH}$ değerleri $\mathrm{pH}$-metreyle, asitlik ve tuz miktarları titrasyon yöntemiyle, yağ miktarı Gerber metoduyla ve rutubet miktarı gravimetrik yöntemle tespit edilerek örneklerin kimyasal özellikler açısından standartlara uygun olup olmadıkları belirlendi. Sonuç olarak incelenen kaşar peyniri örneklerinden $\% 28$ 'inin tuz ve $\% 40$ 'ının rutubet; çeçil peyniri örneklerinden $\% 60$ 'ının tuz ve $\% 40$ 'ının rutubet; lor örneklerinden $\% 4$ 'ünün L. monocytogenes, $\% 20$ 'sinin tuz ve $\% 28$ 'inin rutubet; beyaz peynir örneklerinden \%8'inin L. monocytogenes, \%48'inin tuz ve \%28'inin rutubet yönünden Türk Standartlarında belirtilen kriterlere uygun olmadığı belirlendi. Elde edilen sonuçlar doğrultusunda incelenen peynir örneklerinin bazılarının mikrobiyolojik açıdan risk oluşturabileceği ve kimyasal yönden de ilgili standartlara uymadığı belirlendi.

Anahtar kelimeler: Kaşar, çeçil, lor, beyaz peynir, mikrobiyolojik, kimyasal.

\section{Introduction}

Cheese is an important food that contains essential amino acids that cannot be synthesized by our body and is rich in protein, mineral and vitamin content. Cheese, which is indispensable for breakfast tables,

\footnotetext{
*Sorumlu yazar: sezenharmankaya@hotmail.com.tr Geliş Tarihi: 11.12.2019, Kabul Tarihi: 23.06.2020
} 
has a very important place in human nutrition because of its superior composition. More than 1000 different types of cheese are produced worldwide while produced by the impact of different cultures in Turkey there are 150 varieties of cheese from more [1].

Cheese, which has hundreds of varieties and holds a very important place in human nutrition, also has important chemical and microbiological qualities. The microorganisms found in cheese cause changes in the structure of the cheese, negatively affecting its quality, and can lead to food poisoning as a result. Many bacteria that can threaten public health can be found in the natural flora of milk. At the same time, the processes applied during heat treatment and production should be controlled as much as possible because they also affect the overall quality of milk [2]. Inadequate pasteurization of milk used in cheese production and bacterial contamination of holding conditions during maturation negatively affect the development and quality of cheese microflora $[3,4]$. In studies of the microbiological quality of cheeses, it has been expressed that many microorganisms that negatively affect the quality of cheese and species that threaten human health have been isolated in cheese samples. Foremostamong those mentioned include E. coli, coliform group bacteria, Salmonella species, L. monocytogenes, Staphylococcus aureus, yeast and mold [5]. In one of these studies, coliform group bacteria, E. coli, S. aureus and fecal Streptococci were found in tulumcheese samples in different packages procured from the Istanbul market [6].

In a study, Enterobacteriaceae, coliform and $S$. aureus were found in herbycheese samples collected from various sales points in Van city center [7]. In another study, it was stated that $90.5 \%$ of 42 kashar cheese samples failed to comply with the TSE (Turkish Standards Institute) standards due to pathogenic bacterial load [8]. In a study in which microbiological and chemical properties of Divle cheese, a type of cheese from the Konya, Karaman and Ereğli region, were investigated, it was reported that consumption of Divletulum cheeses posed potentially serious risks to public health because of containing varying levels of microorganisms and also many pathogens and non-pathogenic microorganisms [9]. In a study which investigated the microbiological quality of civil cheeses obtained from Erzurum region, according to the microbiological analysis results, it was concluded that civil cheese may cause a potential risk for public health [10].

Cheese production has held an important place in the Kars economy since the 1870s. Around 16 dairy farms were first established by Swiss, Armenian, Greek, Russian and Georgian cheese producers in the region of Kars and nearby districts [11]. More than 10 different types of cheese, mainly kashar and gruyere-type, are produced in this region [1]. Although the history of cheese-making is very old, most of today's production is provided by small family farms and dairies in the region. As the raw material of cheese is milk, investigating the microbiological characteristics of the product at every stage from production to consumption is very important. This study aimed to investigate the microbiological and chemical quality of different cheese varieties obtained from the Kars market and to find solutions to possible risks or shortcomings of the Kars cheese industry, which holds a very important place in the region in cultural and economic terms.

\section{Material and Methods}

Cheese samples: In order to examine the microbiological and chemical quality of the cheese offered in the market, 100 cheese samples, including 25 of kashar cheese, 25 of chechil cheese, 25 of lor and 25 of white cheese were supplied from sales points at the centre of Kars. Without interfering with the vendors' routine sales procedures and packaging, each 500-g cheese sample was then placed in heatinsulated containers and kept cold. Samples were brought to the laboratory within 30-60 minutes after they were taken from the market and analyzed for microbiological and chemical properties.

\subsection{Microbiological Analyses}

The cheese samples, weighing $500 \mathrm{~g}$, were taken from the packaging material using sterile forceps and a spatula, transferred into sterile bags and then broken up and mashed by applying pressure and pounding the bag. For each cheese sample, $10 \mathrm{~g}$ were weighted and diluted aseptically in $90 \mathrm{~mL}$ of citrate buffer and homogenised in a sterile bag using a stomacher for $2 \mathrm{~min}$. The complete decimal serial dilutions till $10^{-6}$ of the samples were prepared and inoculated using pour and spread techniques under the following incubation conditions. The details of the methods used for microbiological analyses are shown in Table 
1.All colonies produced on Plate Count Agar (PCA) were aerobic mesophilic bacteria [12, 13]; dark red colonies $0.5 \mathrm{~mm}$ in diameter or larger cultured on Violet Red Bile Lactose Agar (VL) were coliform bacteria [14]; blue-green colonies grown on Tryptone Bile X-Glucuronide medium (TBX) were E. coli $[15,16]$; all red colored and oxidase (-) colonies 1-2 mm in diameter cultured on Violet Red Bile Glucose Agar (VG) were Enterobacteriaceae [13, 17]; black colonies formed on Baird Parker Agar (BPA) were evaluated as Staphylococci-Micrococci [13]; all colonies cultured on Potato Dextrose Agar (PDA) were yeast-mold [14]. To analyze the presence of Salmonella spp., and L. monocytogenes $25 \mathrm{~g}$ samples were pre-enriched and incubated at $37^{\circ} \mathrm{C}$ for $24 \mathrm{~h}, 30^{\circ} \mathrm{C}$ for $24 \mathrm{~h}$, respectively. $225 \mathrm{~mL}$ Buffered Pepton Water (Oxoid CM509, UK) and 225 mL Buffered Listeria Enrichment Broth (Oxoid CM897, UK) respectively were used for selective enrichment. Samples homogenized for 2 minutes. For the inoculation, incubation and identification were applied according to the methods specified in TSE standards $[18,19]$. Selected typical 5 suspected colonies for Salmonella spp. (Oxoid DR1108, UK) and L. monocytogenes (Oxoid MB1128A, UK) were confirmed with serological and biochemical test kits.

The appropriate amount of the homogenized cheese samples were taken and made ready for chemical analyses.

\subsection{Chemical Analyses}

The $\mathrm{pH}$ values of the samples were measured using a $\mathrm{pH}$-meter and determined according to the method of Bianco et al. [20]. The acidity and salt contents of the samples were determined by titration method, the fat content was analyzed using the Gerber method and the moisture content was determined by the gravimetric method [21].

Table1.Media used in microbiological analysis and incubation conditions of bacteria

\begin{tabular}{|c|c|c|c|c|}
\hline Group of bacteria & Medium & $\begin{array}{l}\text { Incubation } \\
\text { temperature }\end{array}$ & $\begin{array}{c}\text { Incubation } \\
\text { time }\end{array}$ & $\begin{array}{l}\text { Incubation } \\
\text { atmosphere }\end{array}$ \\
\hline $\begin{array}{c}\text { Total aerob mesophilic } \\
\text { bacteria }\end{array}$ & $\begin{array}{c}\text { Plate Count Agar (PCA) } \\
\text { (Oxoid CM0325) }\end{array}$ & $30^{\circ} \mathrm{C}$ & 48 hour & Aerobic \\
\hline Coliform & $\begin{array}{l}\text { Violet Red Bile Lactose Agar } \\
\text { (VL) (Oxoid CM0107) }\end{array}$ & $37^{\circ} \mathrm{C}$ & 48 hour & $\begin{array}{c}\text { Facultative } \\
\text { Aerobic }\end{array}$ \\
\hline Escherichia coli & TBX Medium (Oxoid CM0945) & 44.5 & 24 hour & Aerobic \\
\hline Enterobacteriaceae & $\begin{array}{l}\text { Violet Red Bile Glucose Agar } \\
\text { (VG) (Oxoid CM0485) }\end{array}$ & $35^{\circ} \mathrm{C}$ & 48 hour & $\begin{array}{c}\text { Facultative } \\
\text { Aerobic }\end{array}$ \\
\hline $\begin{array}{c}\text { Staphylococci- } \\
\text { Micrococci }\end{array}$ & $\begin{array}{c}\text { Baird Parker Agar (BP) } \\
\text { (Oxoid CM0275) }\end{array}$ & $37^{\circ} \mathrm{C}$ & 24 hour & Aerobic \\
\hline Yeast-Mold & $\begin{array}{l}\text { Potado Dextrose Agar (PDA) } \\
\text { (BAM Media M127) }\end{array}$ & $25^{\circ} \mathrm{C}$ & 4-5 day & Aerobic \\
\hline Salmonella spp. & $\begin{array}{l}\text { Brillant Green Phenol Red Agar } \\
\text { (Modified) (Oxoid CM0329) } \\
\text { Xylose-Lysine-Desoxycholate } \\
\text { Agar (XLD) (Labm LAB 032) }\end{array}$ & $37^{\circ} \mathrm{C}$ & 24 hour & Aerobic \\
\hline Listeria monocytogenes & $\begin{array}{l}\text { Listeria Selective Agar Base } \\
\text { (Oxoid CM0856) }\end{array}$ & $30^{\circ} \mathrm{C}$ & 24 hour & Aerobic \\
\hline
\end{tabular}




\subsection{Statistical analyses}

The data obtained as a result of the research were subjected to variance analysis via the SPSS PASW Statistics 18 package program and the results were given as mean \pm standard deviation.

\section{Results and Discussion}

As a result, of the kashar cheese samples, 7 (28\%) in terms of salt content and $10(40 \%)$ in terms of moisture content did not meet Turkish standards. Of the chechil cheese samples, $15(60 \%)$ in terms of salt content and $10(40 \%)$ in terms of moisture content did not meet Turkish standards. Of the lor samples, 1 (4\%) contained L. monocytogenes, while $5(20 \%)$ in terms of salt content and $7(28 \%)$ in terms of moisture content did not meet Turkish standards. Of the examined white cheese samples, 2 (8\%) contained L. monocytogenes, while $12(48 \%)$ in terms of salt content and $7(28 \%)$ in terms of moisture content did not meet Turkish standards. The microbiological analysis results of all cheeses are given in Tables 2 and 3. Chemical analysis findings of the kashar, chechil, lor and white cheeses evaluated according to the Turkish Food Codex Cheese Communiqué [21] are given in Tables 4 and 5.

When the microbiological data of the samples collected from the market were analyzed, it was found that the microbial load varied from sample to the sample.

The average TAMB count in the kashar cheese samples was $1.2 \times 10^{8} \mathrm{cfu} / \mathrm{g}$. This result was higher than that reported by Kamber [22] $\left(7.03 \log _{10} \mathrm{cfu} / \mathrm{g}\right)$ and Öksüztepe et al. [26] $\left(1.1 \times 10^{7} \mathrm{cfu} / \mathrm{g}\right)$. Although there is no limitation for TAMB in the Turkish cheese standard, these pathogenic bacteria values are at a level that could threaten public health. This may be due to a lack of hygiene during the production or sales phase. In this study, the average coliform group bacteria count in kashar cheese was found to be $0.66 \times 10^{1} \mathrm{cfu} / \mathrm{g}$. These results were lower than those of Gülmez et al. [27] $\left(1.16 \times 10^{2} \mathrm{cfu} / \mathrm{g}\right)$ and Kamber [22] (3.91 $\left.\log _{10} \mathrm{cfu} / \mathrm{g}\right)$. In none of the kashar samples, E. coli was not found, and this microorganism poses a risk for food safety as well as endangering the formation of cheeses [3]. The Enterobacteriaceae count $\left(3.5 \times 10^{1} \mathrm{cfu} / \mathrm{g}\right)$ was also found to be lower than that reported by Kamber (22) $\left(4.30 \log _{10} \mathrm{cfu} / \mathrm{g}\right)$. The average Staphylococci-Micrococci count was $8.30 \times 10^{1} \mathrm{cfu} / \mathrm{g}$, which was lower than that found by Öksüztepe et al. [26] $\left(1.4 \times 10^{2} \mathrm{cfu} / \mathrm{g}\right)$. The yeast-mold count $\left(3.82 \times 10^{1} \mathrm{cfu} / \mathrm{g}\right)$ was similar to the results of Kamber [22], with $6.04 \log _{10} \mathrm{cfu} / \mathrm{g}$, but lower than those of Gülmez et al. [27] $\left(3.8 \times 10^{8} \mathrm{cfu} / \mathrm{g}\right)$. Neither L. monocytogenes nor Salmonella spp. were present in any of the kashar cheese samples.

The average TAMB count found in the samples of chechil cheese was $1.2 \times 10^{8} \mathrm{cfu} / \mathrm{g}$. This result was higher than the results of Kamber [22] (7.253 $\left.\log _{10} \mathrm{cfu} / \mathrm{g}\right)$ and of Yangilar and Kizılkaya [23] (7.97 $\left.\log _{10} \mathrm{cfu} / \mathrm{g}\right)$, while lower than that of Gülmez and Güven [24] $\left(1.1 \times 10^{9} \mathrm{cfu} / \mathrm{g}\right)$. This situation may have been caused by many factors, such as the differences in pasteurization processes applied to the milk or ripening times of the cheese. Kamber [22], in his study, found the number of coliform bacteria in chechil cheese to be on average $4.35 \log _{10} \mathrm{cfu} / \mathrm{g}$, while the number determined by Gülmez and Güven [24] was $2.8 \times 10^{5} \mathrm{cfu} / \mathrm{g}$. In the present study, in contrast, the coliform bacteria count was found to be quite low $\left(1.9 \times 10^{1} \mathrm{cfu} / \mathrm{g}\right)$. The presence of coliform bacteria in foods indicates inadequate or incorrect heat treatment applications or poor hygiene conditions [3]. The average E. coli count was found to be $0.14 \times 10^{1} \mathrm{cfu} / \mathrm{g}$ in two samples. The presence of this bacterium may indicate a fecal source of contamination as well as the presence of pathogenic microorganisms in the environment [25]. The Enterobacteriaceae count was recorded as $1.9 \times 10^{2} \mathrm{cfu} / \mathrm{g}$, whereas the study by Kamber [22] found a higher number of Enterobacteriaceae (3.47 $\log _{10} \mathrm{cfu} / \mathrm{g}$ ). The average Staphylococci-Micrococci count was found to be $1.65 \times 10^{2} \mathrm{cfu} / \mathrm{g}$. The yeast-mold count was determined as $4.31 \times 10^{6}$, similar to the result of Kamber [22] (6.454 $\left.\log _{10} \mathrm{cfu} / \mathrm{g}\right)$, wherein it was lower than the result of Gülmez and Güven [24] $\left(6.8 \times 10^{8} \mathrm{cfu} / \mathrm{g}\right)$. L. monocytogenes and Salmonella spp. were not detected in any of the samples of chechil cheese.

In the lor samples, the TAMB count was determined as $7.73 \times 10^{8} \mathrm{cfu} / \mathrm{g}$. This result showed a similarity to that reported by Sert and Kıvanç (34) $\left(1.9 \times 10^{8} \mathrm{cfu} / \mathrm{g}\right)$, while it was lower than the results of Kızanlık-Koçak and Göksoy [29] $\left(9.80 \log _{10} \mathrm{cfu} / \mathrm{g}\right)$. The average coliform bacteria count was $1.66 \times 10^{1}$ $\mathrm{cfu} / \mathrm{g}$, which was lower than the results of Sert and Kıvanç [34] $\left(1.1 \times 10^{3} \mathrm{cfu} / \mathrm{g}\right)$. The E. coli count was $0.28 \times 10^{1} \mathrm{cfu} / \mathrm{g}$, lower than the result of Sert and Kıvanç [34] $\left(4.37 \times 10^{2} \mathrm{cfu} / \mathrm{g}\right)$. The Enterobacteriaceae count was $5.9 \times 10^{1} \mathrm{cfu} / \mathrm{g}$ and the Staphylococci-Micrococci count was $9.59 \times 10^{1} \mathrm{cfu} / \mathrm{g}$. The yeast-mold 
count was determined as $2.21 \times 10^{6} \mathrm{cfu} / \mathrm{g}$, similar to the results of Sert and Kıvanç [34] $\left(1.9 \times 10^{8} \mathrm{cfu} / \mathrm{g}\right)$. L. monocytogenes $\left(0.04 \times 10^{1} \mathrm{cfu} / \mathrm{g}\right)$ was detected in one lor sample, whereas none of the samples exhibited the presence of Salmonella spp. L. monocytogenes is a pathogenic bacterium which, according to Turkish standards, should not be found in cheese as it can cause serious health problems such as meningitis, septicemia, and abortion [3].

The average TAMB count in the white cheese samples was found to be $7.3 \times 10^{8} \mathrm{cfu} / \mathrm{g}$, whereas the number found by Sağun et al. [28] was lower $\left(7.25 \log _{10} \mathrm{cfu} / \mathrm{g}\right)$, and that found by Kızanlık-Koçak and Göksoy [29] was higher $\left(9.43 \log _{10} \mathrm{cfu} / \mathrm{g}\right)$. The coliform bacteria count found $\left(0.84 \times 10^{1} \mathrm{cfu} / \mathrm{g}\right)$ was similar to that reported by Sağun et al. [28] $\left(1.06 \log _{10} \mathrm{cfu} / \mathrm{g}\right)$. In this study, E. coli was not detected in any of the white cheese samples, although in another study on raw milk and white cheese samples in the Kars Province, E. coli was isolated in all the samples of white cheese [30]. In the tested samples Enterobacteriaceae count was $9.28 \times 10^{1} \mathrm{cfu} / \mathrm{g}$. Similarly, the Staphylococci-Micrococci count $\left(1.18 \times 10^{1}\right.$ $\mathrm{cfu} / \mathrm{g}$ ) was also close to that reported by Sağun et al. [28]. In the tested samples yeast-mold count was $2.85 \times 10^{6} \mathrm{cfu} / \mathrm{g}$. L. monocytogenes must not be found in food samples. In a study, samples of white cheese and chechil cheese offered for sale in Kars Province were examined for Campylobacter, Salmonella and Listeria species and L. monocytogenes was found in 5\% of the fresh cheese samples. In another study, L. monocytogenes in 3\% of the white cheese samples [31] while in the present study, $L$. monocytogenes was detected in $8 \%$ of the white cheese samples that might also cause the public health risks. This is an indication that the milk had not been sufficiently pasteurized [3]. In order to control Salmonella contamination and infection, it is necessary to regularly analyze the presence of Salmonella in food. Similar to the results obtained in the present study, no Salmonella was detected in the cheese samples in another study performed for evaluating the microbiological quality of cheese samples sold in Ankara [32]. However, Salmonella species were found in $2 \%$ of cheese samples in another study conducted with white cheese obtained from distinct markets in central Afyonkarahisar Province [33].

In a study that examined samples of Kars kashar cheese, it was reported that $92 \%$ and $38 \%$ of the samples failed to meet the standards in terms of moisture content and dry matter salt content, respectively [24]. Similarly in this study, $40 \%$ of the kashar cheese samples in terms of moisture and $28 \%$ in terms of salt did not meet Turkish standards. This may be due to the manufacturer's failure to use a standard method. In this study, the fat content of the chechil cheese was between $14.3 \%$ and $22.6 \%$. This result is higher than that found by Yangilar and Kizilkaya [23] (7.43\%-12.55\%). In this study, the fat content in lor cheese was found between $7.21 \%$ and $13.3 \%$. As in this study, fat rates were found different in other studies [35, 36, 37]. This difference may be due to the difference in the amount of fat used in milk production in cheese. In this study, $80 \%$ of the white cheese samples were found to be semi-skimmed and 20\% low-fat. This result is similar to the results of Gülmez et. al. [27]. 
Table 2. Results of microbiological analysis of kashar and chechil cheeses (cfu/g)

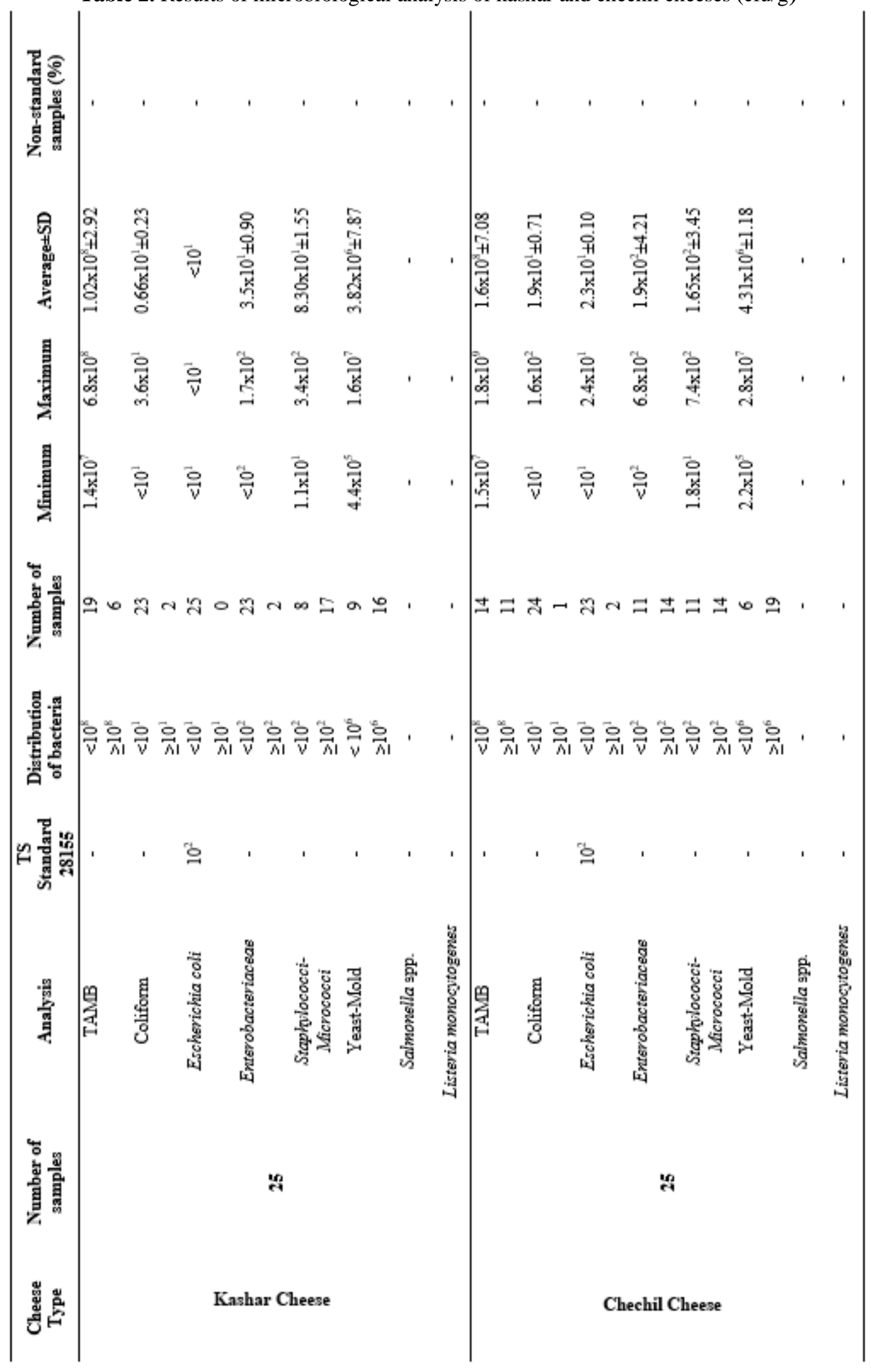


Table 3. Results of microbiological analysis of lor and white cheeses (log cfu/g)

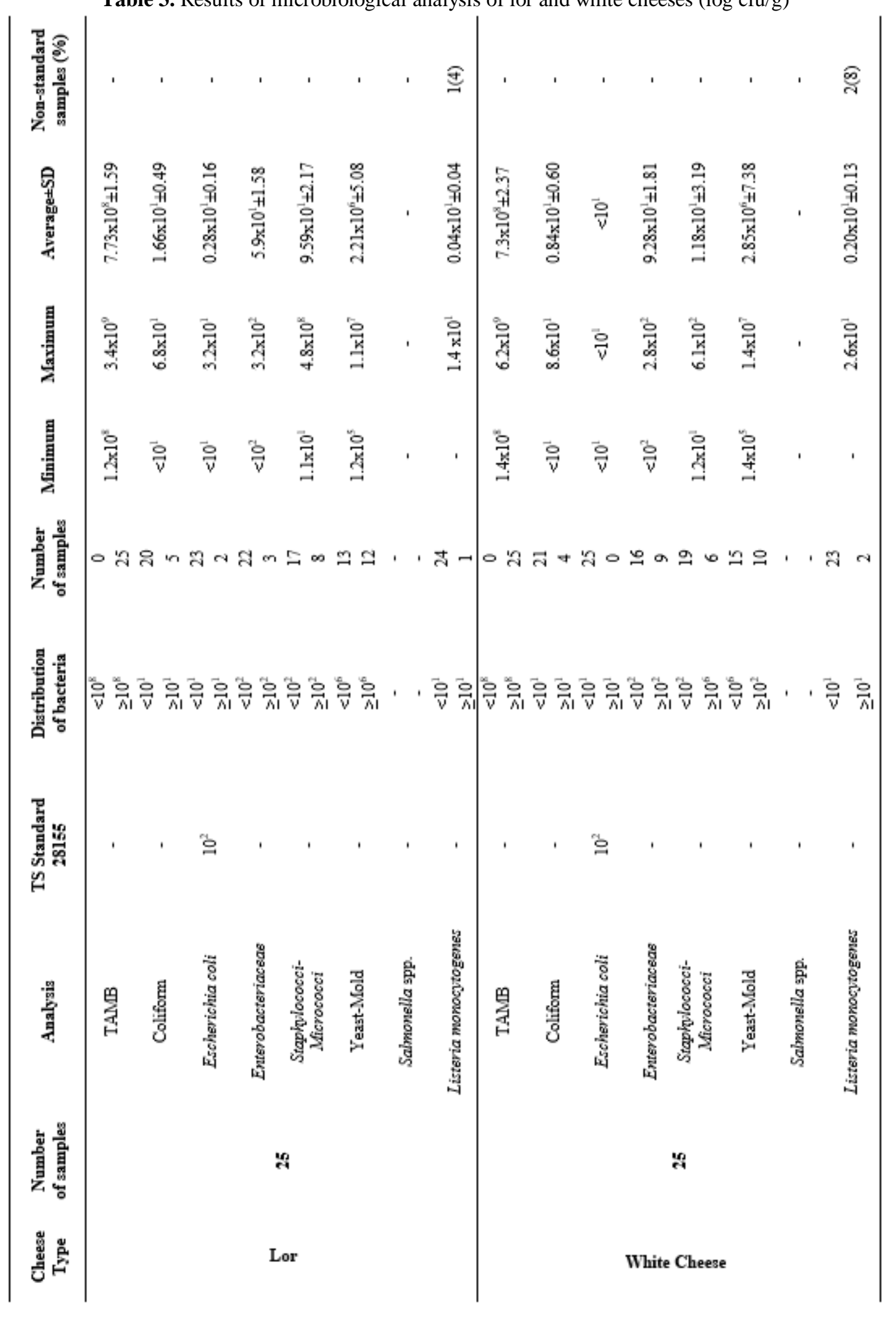


Table 4. Results of chemical analysis of kashar and chechil cheeses (log cfu/g)

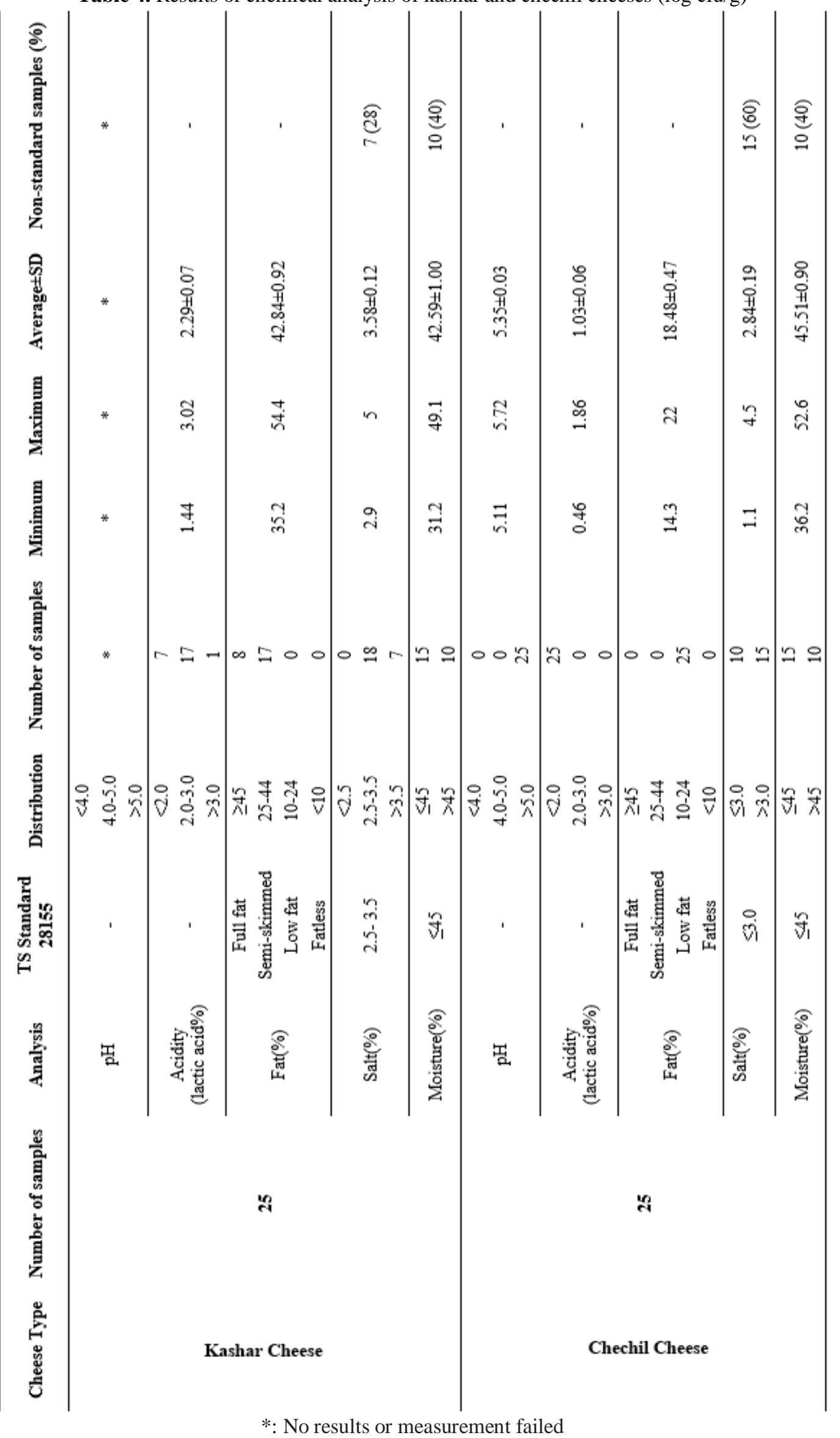




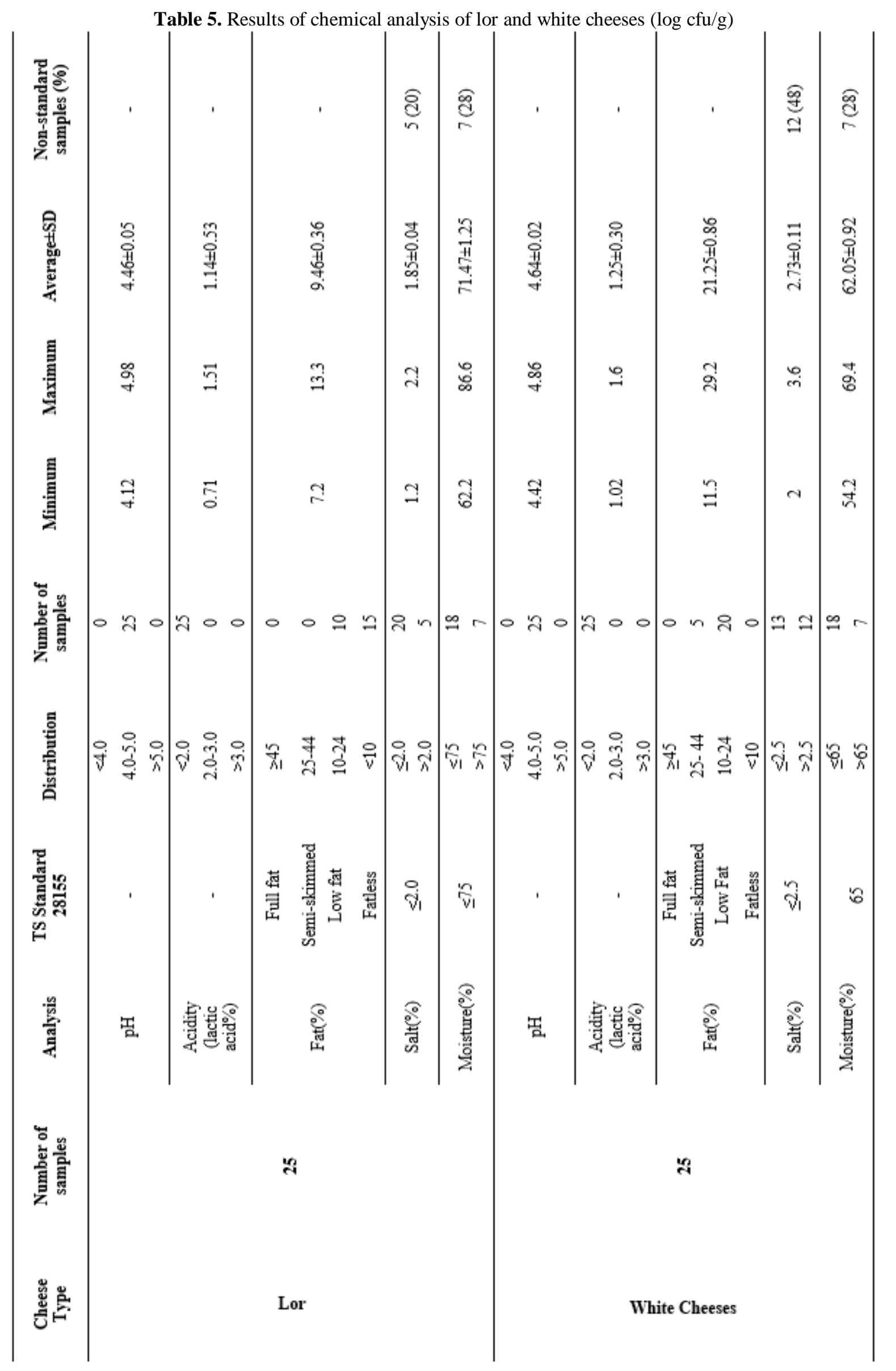




\section{Conclusion and Suggestions}

As a result, according to the results obtained, many of the cheese samples might pose a microbiological risk and moreover, were shown to be chemically and microbiologically sub-standard. This situation shows the deficiencies in the quality of cheeses and poses a potential threat to public health. In this situation, hygiene rules must be followed throughout all stages of cheese production, from the processing stage to the marketing stage, by using pasteurized and standardized milk, using a starter culture and using suitable processing and packaging methods. Cheese production can also be improved by raising the awareness of the small family businesses that play a major role in the market share. Thus, it will be possible to obtain a more standard, hygienic and high-quality product. As in all food sectors, support must be provided for more discerning and controlled production and marketing opportunities in terms of milk and dairy products. The aim of this study was to provide a reference to encourage more detailed microbiological and chemical studies in order to offer healthful and safe cheese to the public. Kars cheeses, predominantly kashar, hold a very important place in the Kars market as well as throughout the whole of Turkey. For this, the production of Kars cheeses in hygienic conditions and in accordance with the standards is important for the protection of public health.

\section{Acknowledgment}

This research was supported by the Kafkas University Scientific Research Projects Coordination Unit (Project no. 2016-TS-27). Three different data obtained from this study are summarized in three different congresses (poster presentation "Some Microbiological Properties of Kars Kashar and Cecil Cheeses" ICRES 2018; poster presentation "Some Chemical Properties of Kars Kashar and Cecil Cheeses" EurasianBioChem 2018; oral presentation "Some Chemical Properties of Kars White Cheeses and Whey Cheeses" ITWCCST 2018).

\section{Author' Contributions}

The author gave final approval of the current version and any revised version to be submitted to the journal.

\section{Statement of Conflicts of Interest}

No potential conflict of interest was reported by the authors.

\section{Statement of Research and Publication Ethics}

The authors declare that this study complies with Research and Publication Ethics.

\section{References}

[1] Kamber U. 2005. Geleneksel Anadolu Peynirleri. Miki Matbaacılık San. ve Ltd. Şti, Ankara.

[2] Varga L. 2007. Microbiological quality of commercial dairy products. Pages 487-494 in Communicating Current Research and Educational Topics and Trends in Applied Microbiology. Formatex Microbiology Series; (1). A. Mendez-Vilas, ed. Formatex, Badajoz, Spain.

[3] Kılıç S. 2010. Süt Mikrobiyolojisi. Sidaş Medya Ltd. Şti, İzmir.

[4] Kongo J.M., Malkata F.X. 2016. Cheese: Chemistry and Microbiology. Elsevier Ltd. All rights reserved, 735-740.

[5] Kaynar P. 2011. Ülkemiz peynirleri üzerine mikrobiyolojik araştırmalar. Türk Mikrobiyol Cem Derg, 41 (1): 1-8.

[6] Bostan K. 1994. Değişik ambalajlar içinde bulunan tulum peynirlerinin duyusal, kimyasal ve mikrobiyolojik özellikleri. In: Demirci M. (Editör), Her Yönüyle Peynir Kitabı, Trakya Üniv Tekirdağ Ziraat Fakültesi Yayınları, Tekirdağ, 244-248.

[7] Ekici K., Okut H., Isleyici O., Sancak Y.C., Tuncay R.B. 2019. The determination of some microbiological and chemical features in herby cheese. Foods, 8 (23): 1-11. 
[8] Oktay İ., Heperken D., Kaya G.D. 2006. Peynir, tereyağı ve kumpirde patojen mikroorganizmalar ve hızlı test yöntemi vidas ile Listeria ve Salmonella aranması. Dokuzuncu Gıda Kongresi Kitabı, Bolu, Türkiye, 643.

[9] Morul F., İşleyici Ö. 2012. Divle tulum peynirinin kimyasal ve mikrobiyolojik özellikleri. YYÜ Vet Fak Derg, 23 (2): 71-76.

[10] Başkaya R., Atasever M., Çakmak Ö., Yıldız A. 2006. Civil peynirlerin mikrobiyolojik nitelikleri. İÜ Vet Fak Derg, 32: 1-13.

[11] Koçulu İ., Kayacan G., Tatari F., Torun O., Ünsal D. 2014. Alplerden Kafkaslara Kars Peynirciliğinin 150 Yıllık Tarihi. Boğatepe Çevre ve Yaşam Derneği, Tarih Vakfı, Ofset Matbaacilık, İstanbul.

[12] Messer J.W., Behney H.M., Leudecke L.O. 1985. Mikrobiological Count Methods. In: Richardson G.H. (Editor). Standart Methods for the Examination of Dairy Products, 15. Edition, 133-149.

[13] Anonymous, 1995. The Oxoid Manual. Compiled By EY Bridson, 7th. Ed. Oxoid Ltd. Basingstoke, Hampshire.

[14] Koburger J.A., Marth E.H. 1984. Yeasts and Molds. In: Speck M.L. (Editor), Compendium of Methods for the Microbiological Examination of Food, 197-201.

[15] Anonymous, 2001. Microbiology of Food and Animal Feeding Stuffs-Horizontal Method for the Enumeration of ß-Glucuronidase-Positive Escherichia coli. Part 2: Colony-Count Technique A $44^{\circ} \mathrm{C}$ Using 5-Bromo-4-Chloro-3-Indoyl-Beta-D-Glucuronide, ISO 16649-2.

[16] Pichhardt K. 1993. Lebensmittel mikrobiologie. 3. Auflage, Springer Verlag, Berlin.

[17] Anonymous, 1997. International Organization for Standardization: Meat and Meat ProductsDetection and Enumeration of Enterobacteriaceae. ISO/DIS 5552.

[18] Türk Standartları Enstitüsü. 2004. Gıda ve yem maddelerinin mikrobiyolojisi-Listeria monocytogenes'in aranmas1 ve sayımı metodu. Bölüm-1: arama metod. TSE EN ISO 112901/A1; ss.1-9. Türk Standartları Enstitüsü, Ankara.

[19] Türk Standartları Enstitüsü. 2017. Besin zincirinin mikrobiyolojisi- Salmonella 'nıntespiti sayımı ve serotiplendirilmesi için yatay yöntem. Bölüm-1: Salmonella spp. TSE EN ISO 6579-1; ss. 167. Türk Standartları Enstitüsü, Ankara.

[20] Bianco L.J., Peter B.M., Mykleby W.R., Burke J.A. 1972. Supplemental chemical control methods, In: Hausler W.J. (Editor), Standart Methods fort the Examination of Dairy Products. Thirteen Ed. A.P.H.A, 320-322.

[21] Kurt A., Çakmakcı S., Çağlar A. 1993. Süt ve Mamülleri Muayene ve Analiz Metodları Rehberi. Genişletilmiş 5. Bask1, Atatürk Üniv. Yayınları No: 252/D, Ziraat Fak Yay No: 18, Erzurum.

[22] Kamber U. 2005. Kars'ta satışa sunulan kaşar ve çeçil (civil) peynirlerinin bazı mikrobiyolojik ve kimyasal kalite nitelikleri. Kafkas Üniv Vet Fak Derg, 11 (1): 33-35.

[23] Yangılar F., Kızılkaya P.Ç. 2015. Ardahan'ın aromatik çeçil peynirlerinin mikrobiyolojik ve kimyasal özelliklerinin belirlenmesi.BEÜ Fen Bilimleri Derg, 4 (2): 122-130.

[24] Gülmez M., Güven A. 2001. Beyaz ve çeçil peynirlerinde Campylobacter, Salmonella ve Listeria türlerinin araştırılması. Kafkas Üniv Vet Fak Derg, 7: 155-161.

[25] Erol İ. 2007. Gida Hijyeni ve Mikrobiyolojisi. Pozitif Maatbacılık Ltd. Şti. Ankara.

[26] Öksüztepe G., Patır B., Dikici A., İlhak O.İ. 2009. Elazığ' da tüketime sunulan vakum paketli taze kaşar peynirlerinin mikrobiyolojik ve kimyasal kalitesi. Fırat Üniv Sağ Bil Vet Derg, 23 (2): 8994.

[27] Gülmez M., Güven A., Çetinkaya A. 2001. Kars'ta tüketime sunulan taze ve salamura beyaz peynirlerin bazı mikrobiyolojik ve kimyasal özellikleri. Kafkas Üniv Vet Fak Derg, 7 (1): 55-62.

[28] Sağun E., Sancak H., Durmaz H. 2001. Van'da kahvaltı salonlarında tüketime sunulan süt ürünlerinin mikrobiyolojik ve kimyasal kaliteleri üzerine bir araştırma. YYÜ Vet Fak Derg, 12 (1-2): 108-112.

[29] Kızanlık-Koçak P., Göksoy E.Ö. 2018. Microbiological quality evaluation of various types of cheese.Erciyes Üniv Vet Fak Derg, 15 (2): 86-93.

[30] Baz E., Gülmez M., Güven A., Sezer Ç., Duman B. 2003. Kars’ta satışa sunulan çiğ süt ve taze beyaz peynirlerin koliform grubu bakterileri, E. coli ve E. coli O157:H7 yönünden incelenmesi.Kafkas Üniv Vet Fak Derg, 9 (2): 165-167. 
[31] Aksoy A., Sezer Ç., Vatansever L., Gülbaz G. 2018. Presence and antibiotic resistance of Listeria monocytogenes in raw milk and dairy products. Kafkas Üniv Vet Fak Derg, 24 (3): 415-421.

[32] Kaynar Z., Kaynar P., Koçak C. 2005. Ankara piyasasında tüketime sunulan beyaz peynirlerin hijyenik kalitelerinin belirlenmesi üzerine bir araştırma. Türk Hij Den Biyol Derg, 62 (1,2,3): 110.

[33] Akkaya L., Alişarlı M. 2006. Afyonkarahisar'da tüketime sunulan peynirlerde Listeria monocytogenes ve Salmonella türlerinin varlığının belirlenmesi. YYÜ Vet Fak Derg, 17 (1-2): 87-91.

[34] Sert S., Kıvanç M. 1985. Taze civil ve lor peyniri üzerinde mikrobiyolojik çalışmalar. Gıda, 10 (5): 287-292.

[35] Çardak A.D. 2012. Microbiological and chemical quality of çökelek cheese, lor cheese and torba (strained) yoghurt. African Journal of Microbiology Research, 6: 7278-7284.

[36] Demirci M., Şimşek O., Arıcı M. 1991.Tekirdağ piyasasında satılan lorların bileşimi ve bazımikrobiyolojik özellikleri üzerine bir araştırma. Gida, 16: 291-294.

[37] İncili G.K., Çalıcıoğlu M. 2019. Elazığ ilinde vakum ambalajlı ve açıkta satışa sunulan lor peynirlerinin kimyasal özelliklerinin ve mikrobiyolojik kalitesinin değerlendirilmesi.Fırat Üniv Sağ Bil Vet Derg. 33 (3): 169-175. 